\title{
Preparation of Calcium Phosphate Fibers
}

\author{
Toshihiro KASUGA and Yoshihiro ABE \\ Department of Materials Science and Engineering \\ Nagoya Institute of Technology \\ Gokiso-cho, Showa-ku, Nagoya 466
}

\begin{abstract}
$\quad \beta$-calcium metaphosphate fibers were successfully extracted from crystallized glasses by leaching with distilled water or a dilute $\mathrm{NaOH}$ aqueous solution. The fibers of high aspect ratios (30 120) were obtained from the crystallized glasses of which molar ratio of $\mathrm{CaO} / \mathrm{P}_{2} \mathrm{O}_{5}$ is slightly less than unity. It is expected that the fibers are available for new applications to biomedical fields.
\end{abstract}

\section{Introduction}

Calcium phosphate glasses and glass-ceramics ${ }^{1-5}$ have high potential in use as biomedical materials. It has been reported that $\mathrm{Ca}\left(\mathrm{PO}_{3}\right)_{2}$ glass is nontoxic. ${ }^{1}$ The unidirectionally crystallized glass-ceramic having fiberreinforced composite structure was successfully produced by reheating a calcium phosphate glass rod around the metaphosphate composition under a temperature gradient around the glass transition temperature $(\mathrm{Tg}){ }^{2,3}$ The glass-ceramic composed of crystalline $\beta-\mathrm{Ca}\left(\mathrm{PO}_{3}\right)_{2}$ fibers (diameter; $\approx 1 \mu \mathrm{m})$ shows high mechanical strength (400 600 MPa in bending) and low Young's modulus (70 120 GPa). This result implies that the $\beta-\mathrm{Ca}\left(\mathrm{PO}_{3}\right)_{2}$ fibers are of high-strength and flexibility. In addition, the glass-ceramic shows good biocompatibility. ${ }^{4,5}$ Therefore, it is expected that this fiber can be used for new composite-biomaterials. Our earlier works reported 
that the $\beta-\mathrm{Ca}\left(\mathrm{PO}_{3}\right)_{2}$ fibers are successfully extracted from the crystallized product of a calcium phosphate glass by leaching with distilled water or a dilute $\mathrm{NaOH}$ aqueous solution. ${ }^{6,7}$ In this report the optimal glass composition to obtain the fiber will be discussed.

\section{Experimental Procedure}

Batch mixtures with $\mathrm{CaO} / \mathrm{P}_{2} \mathrm{O}_{5}=0.72 \sim 1.00$ in molar ratio were prepared by using raw materials such as $\mathrm{Ca}\left(\mathrm{H}_{2} \mathrm{PO}_{4}\right)_{2} \cdot \mathrm{H}_{2} \mathrm{O}$ and $\mathrm{H}_{3} \mathrm{PO}_{4}$. The mixtures were melted in a platinum crucible at $1250{ }^{\circ} \mathrm{C}$ for $2 \mathrm{~h}$. The melts were poured onto a carbon plate and cooled to a room temperature. The resultant glasses were reheated at $600{ }^{\circ} \mathrm{C}$ for $48 \mathrm{~h}$ for crystallization. The crystallized glass blocks were crushed into powders below $850 \mu \mathrm{m}$ using an alumina mortar. The powders $(10 \mathrm{~g})$ of the crystallized glasses were put into a tefron vessel filled with $200 \mathrm{ml}$ of leaching solutions to extract $\beta-\mathrm{Ca}\left(\mathrm{PO}_{3}\right)_{2}$ fibers. ${ }^{6}$ Distilled water (DW) or an aqueous solution of $0.1 \mathrm{~N} \mathrm{NaOH}$ were used as the solution. They were stirred at $70^{\circ} \sim 90$ ${ }^{\circ} \mathrm{C}$ for $4 \sim 72 \mathrm{~h}$. The resultant products were filtrated and dried at $150{ }^{\circ} \mathrm{C}$ in air. The crystalline phases in the glasses crystallized and the fibers obtained were identified by X-ray diffraction analysis (XRD). The morphologies of the fibers were observed by scanning electron microscopy (SEM).

\section{Results and Discussion}

Glass-ceramics which contain long fibrous $\beta-\mathrm{Ca}\left(\mathrm{PO}_{3}\right)_{2}$ can be prepared by reheating $\mathrm{CaO}-\mathrm{P}_{2} \mathrm{O}_{5}$ glasses around the metaphosphate composition at the temperature around $\mathrm{Tg}^{2,3,6,7}$ Glass-ceramics converted from the calcium ultraphosphate glasses $\left(\mathrm{CaO} / \mathrm{P}_{2} \mathrm{O}_{5}<1\right)$ consist of crystals such as $\beta-\mathrm{Ca}\left(\mathrm{PO}_{3}\right)_{2}, \mathrm{Ca}_{2} \mathrm{P}_{6} \mathrm{O}_{17}$, and an ultraphosphate glassy phase. ${ }^{3}$ Figure 
1 shows change in $\mathrm{pH}$ values of $\mathrm{NaOH}$ solution as a function of leaching time. The $\mathrm{pH}$ value decreased rapidly at the initial stage of leaching. The decrease in $\mathrm{pH}$ was caused by dissolution of phosphate ions from ultraphosphate glassy and crystalline phases. ${ }^{6}$ XRD analysis showed that a large amount of $\beta-\mathrm{Ca}\left(\mathrm{PO}_{3}\right)_{2}$ crystal exist in the crystallized product of $\mathrm{CaO} \cdot \mathrm{P}_{2} \mathrm{O}_{5}$ glass without the ultraphosphate crystals. It was difficult to obtain a large amount of fibrous products from the $\mathrm{CaO} \cdot \mathrm{P}_{2} \mathrm{O}_{5}$ crystallized glass by DW-treatment for $72 \mathrm{~h}$. On the other hand, $\beta$-Ca $\left(\mathrm{PO}_{3}\right)_{2}$ fibers were released preferentially from the matrix phase of the crystallized glass with $\mathrm{CaO} / \mathrm{P}_{2} \mathrm{O}_{5}=0.85$. The ultraphosphate phases are much poorer in chemical durability than fibrous $\beta-\mathrm{Ca}\left(\mathrm{PO}_{3}\right)_{2}$ crystals. The existence of the ultraphosphate matrix phases in $\beta-\mathrm{Ca}\left(\mathrm{PO}_{3}\right)_{2}$-containing glass-ceramics is essential for this treatment.

Figure 2 shows SEM photographs of the fibrous products obtained by DW-treatment. From XRD analysis, these products contain $\beta-\mathrm{Ca}\left(\mathrm{PO}_{3}\right)_{2}$ and $\mathrm{Ca}_{2} \mathrm{P}_{6} \mathrm{O}_{17}$. Fiber (A) obtained from the crystallized glass with $\mathrm{CaO} / \mathrm{P}_{2} \mathrm{O}_{5}=0.85$ is smaller in diameter and larger in length compared to that $(\mathrm{B})$ with $\mathrm{CaO} / \mathrm{P}_{2} \mathrm{O}_{5}=0.72$. The $\beta-\mathrm{Ca}\left(\mathrm{PO}_{3}\right)_{2}$ crystals precipitated in the glass with $\mathrm{CaO} / \mathrm{P}_{2} \mathrm{O}_{5}=0.72$ may be shorter in length than that with $\mathrm{CaO} / \mathrm{P}_{2} \mathrm{O}_{5}=0.85$. Fiber $(\mathrm{B})$ contains a large amount of $\mathrm{Ca}_{2} \mathrm{P}_{6} \mathrm{O}_{17}$. The ultraphosphate matrix phases were not dissolved out successfully by this treatment. We have reported that $\mathrm{Ca}_{2} \mathrm{P}_{6} \mathrm{O}_{17}$ is dissolved out almost perfectly by $\mathrm{NaOH}$-treatment. ${ }^{6}$ The calcium metaphosphate fibers containing no ultraphosphate phases are obtained by $\mathrm{NaOH}$-treatment of the crystallized glass with $\mathrm{CaO} / \mathrm{P}_{2} \mathrm{O}_{5}=0.85$.

\section{Summary}

In this work we prepared the calcium metaphosphate fibers having high aspect ratios of 30 120 with diameters of $1 \sim 5 \mu \mathrm{m}$ from a crystallized 
glass with $\mathrm{CaO} / \mathrm{P}_{2} \mathrm{O}_{5}=0.85$. It is expected that the fibers are available to fillers for high-strength composite-biomaterials and for biomedical cushions such as a periodontal substitute.

Acknowledgment: The authors would like to express their grateful thanks to Yabashi Industry Co. Ltd. for its support.

Figure 1. Change in $\mathrm{pH}$ values with treatment time at $80^{\circ} \mathrm{C}$ when the crystallized glass powders were immersed into $0.1 \mathrm{~N} \mathrm{NaOH}$ aqueous solution. The numbers in the figure represent the $\mathrm{CaO} / \mathrm{P}_{2} \mathrm{O}_{5}$ ratios (in mol) of the crystallized glasses.
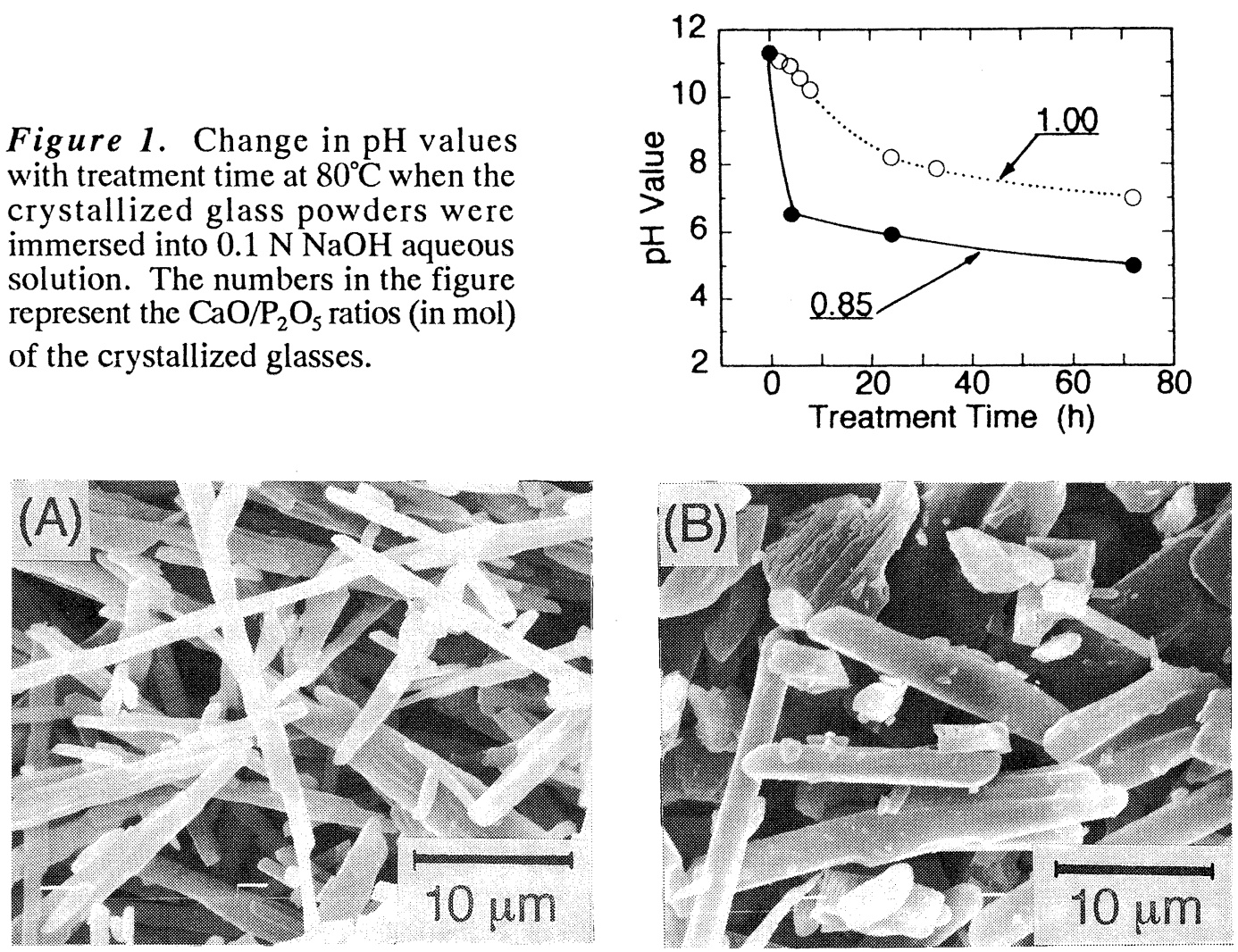

Figure 2. SEM photographs of calcium phosphate fibers obtained by DW-treatment for $72 \mathrm{~h}$. (A): Fibers obtained from the crystallized glass with $\mathrm{CaO} / \mathrm{P}_{2} \mathrm{O}_{5}=0.85$. (B): Fibers obtained the crystallized glass with $\mathrm{CaO} / \mathrm{P}_{2} \mathrm{O}_{5}=0.72$.

\section{References}

[1] M. Nagase, Y.Abe, M. Chigira, and E. Udagawa, Biomaterials, 13, 172 (1992).

[2] Y. Abe, M. Hosoe, T. Kasuga, H. Ishikawa, N. Shinkai, Y. Suzuki, and J. Nakayama, J. Amer. Ceram. Soc., 65, C189 (1982).

[3] Y. Abe, T. Kasuga, H. Hosono, and K. de Groot, J. Amer. Ceram. Soc., 67, C142 (1984).

[4] C.P.A.T. Klein, Y. Abe, H. Hosono, and K. de Groot, Biomaterials, 5, 362 (1984).

[5] idem, ibid, 8, 234 (1987).

[6] T. Kasuga, A. Ichino, and Y. Abe, J. Ceram. Soc. Jpn., 100, 1088 (1992).

[7] T. Kasuga, H. Hosono, and Y. Abe, Phos. Sulf. Silicon, in press. 